\title{
Read the Future Needs of Gas Station Consumers in DKI Jakarta And Banten
}

\author{
Rafdi Dzulfikar Ramdhani*1, Lukman M. Baga ${ }^{2}$, Popong Nurhayati ${ }^{1}$
}

\author{
${ }^{I}$ School of Business, IPB University, Bogor, Indonesia \\ ${ }^{2}$ Faculty of Economics and Management IPB University, Bogor, Indonesia \\ *Corresponding Author E-mail: rafdidr@gmail.com
}

\begin{abstract}
The Business of Gas Stations in DKI Jakarta \& Banten have become an attractive business for investors because of the demand for fuel and the growth in the number of vehicles that continues to increase every year. With so many choices of gas stations in DKI Jakarta \& Banten: PERTAMINA, SHELL, TOTAL, VIVO, BP-AKR. Now consumers have higher bargaining power and growing needs for gas stations. This study aims to analyze the reasons for the selection of gas stations and future consumer needs of gas stations in DKI Jakarta \& Banten using descriptive analysis. Data collection techniques used in descriptive analysis are direct observation and gas stations consumer surveys. Based on descriptive analysis, it is found that access and location that is easy and affordable are the main reasons consumers choose gas stations with $24 \%$, followed by the accuracy of the fuel dose with $22 \%$ and the good quality of services with $17 \%$. Whereas for future consumers needs at gas stations are Food \& Beverages Vending Machine with 30\%, Quick Cleaning with 23\%, and fuels delivery service with $13 \%$.
\end{abstract}

Keywords - Gas station, Bargaining Power, Future Consumer Needs

\section{INTRODUCTION}

Fuel is one of the vital elements of energy needs in a country [1]. Deputy Minister of Energy and Mineral (ESDM) for the period of 2016-2019 Arcandra Tahar stated that in 2017 domestic fuel needs reached 1.3 million barrels per day. This is predicted to increase as the number of vehicles continues to increase every year. The number of vehicles in Indonesia tends to increase significantly from 2007 to 2018 as shown in (Fig 1).

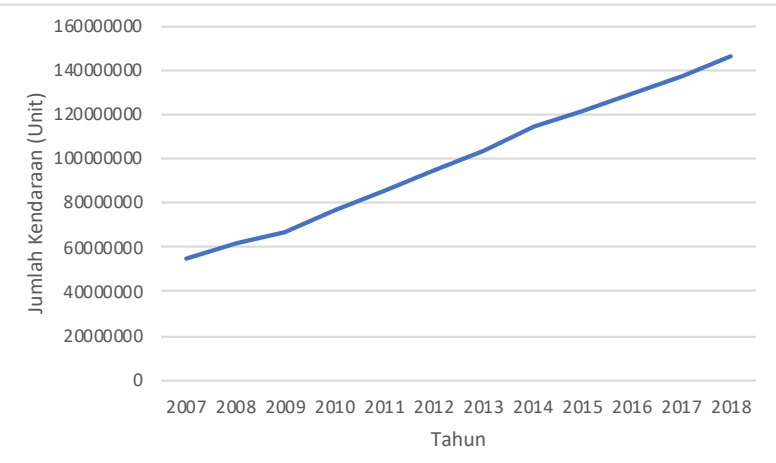

Fig. 1. The number of vehicles in Indonesia from 2007 to 2018

The increasing growth of vehicles in Indonesia will certainly have an impact on increasing domestic fuel consumption. This makes the fuel retail industry in Indonesia very attractive to local and foreign investor. They compete to build a gas station to meet the needs of fuel in Indonesia and compete with a state-owned company: PT PERTAMINA (Persero). Especially since the enactment of law number 5 of 1999 concerning the prohibition of monopolistic practices and unfair business competition and law number 22 of 2001 concerning oil and gas, the role of PT PERTAMINA (Persero) as a fuel regulator and provider was replaced by the Downstream Oil and Gas Regulatory Agency (BPH Migas). Therefore, the business of supplying and distributing fuels can be carried out by any business entity that has obtained a business license from the government, and the price of fuel is left to a fair business competition mechanism. This legal basis is the way for investors and oil and gas companies to enter the fuel retail business in Indonesia by opening gas stations.

SHELL began built a gas station in Indonesia in November 2005 located in Lippo Karawaci, Tangerang. Followed by PETRONAS in December 2005, although PETRONAS finally chose to resign from the Indonesian fuel retail industry in August 2012. Then there were TOTAL who opened their first gas station in March 2009. The latest foreign gas stations are VIVO and BP-AKR which began entering Indonesia respectively in October 2017 and May 2019. Thus, five oil and gas company competing in DKI Jakarta \& Banten. DKI Jakarta \& Banten becomes the target of investors to build gas station. How come, in 2019 recorded that number of registered vehicles in DKI Jakarta \& Banten reached 17.3 million [2]. Plus, vehicles from sub-urban area that come and go make this business promising for investors. 
Regulation of the President of the Republic of Indonesia Number 191, year 2014 concerning Supply, Distribution and Retail Selling Prices of Fuel Oil states that for Fuels with Research Octane Number (RON) 88, the price and distribution are regulated by the Government of Indonesia. Because the fuel with RON 88 is still subsidized by the government since 1967 [3]. The regulation of fuel prices can be used as a basis for bargaining power and political interests even though it becomes difficult to unify prices nationally [4]. Furthermore, they provide legal and social justification for Indonesia to regulate fuel prices, where Indonesia has a national oil company and a state agency in the management of oil and gas.

Now consumers have higher bargaining power and growing needs for gas stations as foreign gas stations comes. They provide different standards and points of view. Previously in the minds of consumers when they want to go to the gas station, there is only one gas station: PERTAMINA, and only one purposes: filling fuel for vehicles. But now various gas station and purposes can be done when consumers go to the gas station, from resting to shopping for food and drinks can be done at the gas station. This makes business opportunities beyond selling fuel such as renting land, parking, toilets, and minimarkets or convenient stores. In certain environments increasing fuel sales do not have an impact on increasing convenient store income in the long run, even though statistically and economically the short term has a significant influence [5]. The reasons for the selection of gas stations and future consumer needs of gas stations in DKI Jakarta \& Banten become the purpose to analyze in this study.

\section{MATERIALS AND METHODS}

\section{A. Methods}

This study aims to analyze the reasons for the selection of gas stations and future consumer needs of gas stations in DKI Jakarta \& Banten. This study began with observe directly and analyze business process in gas station and fuel retail industry in DKI Jakarta \& Banten. Furthermore, create a survey questionnaire for gas station consumers in DKI Jakarta \& Banten. The results of the survey will be analyzed using descriptive analysis to answer the objectives of this study.

\section{B. Descriptive Analysis}

Descriptive analysis is a method used to describe or analyze a research result but is not used to make broader conclusions. Descriptive analysis is an analytical tool used by collecting appropriate data, then the data is compiled, processed, and analyzed to be able to provide a description of the object of research or existing problems [6].

\section{Data Collection Techniques}

The type of collected data consisted of primary and secondary data. Primary data were obtained from direct observation and gas stations consumer surveys. While secondary data were obtained by accessing information and documents held by related institutions as well as other data sources such as books, theses, journals and relevant scientific publications.

\section{Survey}

The survey questionnaire had five sections labeled (respondent profile, primary preferences, alternative preferences, future preferences) consisting of 19 questions. The survey was conducted by distributing questionnaires online to gas station consumers in DKI Jakarta \& Banten who had randomly selected.

\section{RESULTS \& DISCUSSION}

\section{A. Gas Stations Businnes Process}

In running the fuel retail business, gas stations has a business process that consists of fuel procurement, inventory control, and fuel distribution to consumers. The business process is shown in (Fig 2).

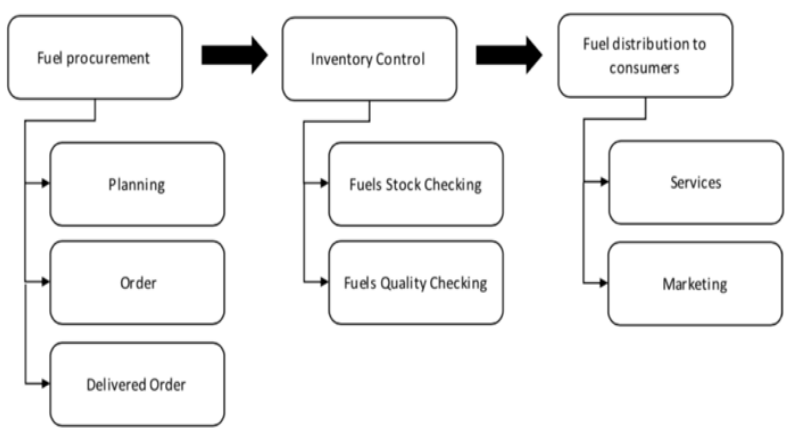

Fig. 2. Gas stations business process

Fuel procurement starts with planning fuel needs for the next 2-3 days. Then, gas stations ordering the fuel through fuels depot. Fuel that has been ordered is then sent by fuels depot and received by the gas station. The gas station ensures that the quality and quantity of fuel received is fit with standard as determined by company. Furthermore, fuel is sold to consumers with service standards and sales strategies set by the company.

\section{B. Condition of Fuel Retail Industry in DKI Jakarta \& Banten}

With 17.3 million number of registered vehicles in DKI Jakarta \& Banten in 2019, fuels become primary needs. Five companies compete to meet consumers needs for fuel in DKI Jakarta \& Banten. Seen from the number of gas stations in January 2020, PERTAMINA 
lead with 390 gas stations. Followed by SHELL WITH 75 gas stations, TOTAL with 15 gas stations, BP AKR with 5 gas stations, and VIVO with 4 gas stations. Thus, the number of gas stations which operate in DKI Jakarta \& Banten is 489 gas stations

\section{Analysis of Surveys Results}

The survey questionnaires were distributed to gas station consumers in DKI Jakarta \& Banten via Google Form. The minimum sample size for descriptive research is 100 respondents [7]. In this study, a total of 129 consumers were obtained with the results $92 \%$ of consumers chose PERTAMINA, 7\% chose SHELL, $1 \%$ chose BP AKR as the primary choice for gas stations they regularly buy as shown in Table 1 .

TABLE 1. PRIMARY AND Alternative Gas Stations CONSUMERS CHOICE

\begin{tabular}{|c|c|c|c|c|}
\hline \multirow[b]{2}{*}{$\begin{array}{c}\text { Gas } \\
\text { Stations }\end{array}$} & \multicolumn{2}{|c|}{ Primary Choice } & \multicolumn{2}{|c|}{ Alternative Choice } \\
\hline & $\begin{array}{c}\text { Number } \\
\text { of } \\
\text { consumers }\end{array}$ & $\begin{array}{c}\text { Percentage } \\
(\%)\end{array}$ & $\begin{array}{c}\begin{array}{c}\text { Number } \\
\text { of } \\
\text { consumers }\end{array} \\
\text { cons }\end{array}$ & $\begin{array}{c}\text { Percentage } \\
(\%)\end{array}$ \\
\hline PERTAMINA & 119 & 92 & 8 & 6 \\
\hline SHELL & 9 & 7 & 112 & 86 \\
\hline TOTAL & 0 & 0 & 5 & 4 \\
\hline BP AKR & 1 & 1 & 2 & 2 \\
\hline VIVO & 0 & 0 & 2 & 2 \\
\hline Total & 129 & 100 & 129 & 100 \\
\hline
\end{tabular}

SHELL became the first alternative gas stations choice by consumers with $86 \%$, followed by PERTAMINA with $7 \%$, TOTAL with $4 \%$, VIVO and BP AKR with $2 \%$ each. As shown in Table 2, it is found that access and location that is easy and affordable are the main reasons consumers choose gas stations with $24 \%$, followed by the accuracy of the fuel dose with $22 \%$ and the good quality of services with $17 \%$. It shows that the numbers and location of gas stations become a key factor to grab consumers in DKI Jakarta \& Banten fuel retail industry. Furthermore, good quality of services and good quantity of fuels still expected from consumers. This key factor must be considered for companies to grab more consumers.

TABLE 2. REASONS FOR CHOOSING GAS STATION

\begin{tabular}{|l|c|c|}
\hline \multicolumn{1}{|c|}{ Reasons } & $\begin{array}{c}\text { Number } \\
\text { of } \\
\text { consumers }\end{array}$ & $\begin{array}{c}\text { Percentage } \\
\text { (\%) }\end{array}$ \\
\hline The good quality of services & 22 & 17 \\
\hline Complete facilities & 6 & 5 \\
\hline $\begin{array}{l}\text { Access and location that is easy and } \\
\text { affordable }\end{array}$ & 31 & 24 \\
\hline Cleanliness & 8 & 6 \\
\hline
\end{tabular}

\begin{tabular}{|l|c|c|}
\hline \multicolumn{1}{|c|}{ Reasons } & $\begin{array}{c}\text { Number } \\
\text { of } \\
\text { consumers }\end{array}$ & $\begin{array}{c}\text { Percentage } \\
\text { (\%) }\end{array}$ \\
\hline The good quality of services & 22 & 17 \\
\hline The accuracy of the fuel dose & 28 & 22 \\
\hline Variance of fuels product & 7 & 5 \\
\hline Fuels quality assurance & 7 & 5 \\
\hline Fuels price & 15 & 12 \\
\hline Variance of payment method & 5 & 4 \\
\hline Attractive promo & 0 & 0 \\
\hline Total & $\mathbf{1 2 9}$ & $\mathbf{1 0 0}$ \\
\hline
\end{tabular}

Table 3 shows how frequently the consumers visit gas stations. The results indicate that $47 \%$ of consumers visit gas stations twice a week, and $22 \%$ of consumers visit gas stations three times a week.

TABLE 3. Vists Per-Week to The Gas Station

\begin{tabular}{|l|c|c|}
\hline \multicolumn{1}{|c|}{ Frequency } & Number of consumers & Percentage (\%) \\
\hline Daily & 2 & 2 \\
\hline Twice & 60 & 47 \\
\hline Three times & 29 & 22 \\
\hline Four times & 7 & 5 \\
\hline Total & $\mathbf{1 2 9}$ & $\mathbf{1 0 0}$ \\
\hline
\end{tabular}

The possibility for consumers to change their gas stations within the next 6 months is shown in Table 4 . $71 \%$ of consumers said they would not change their gas stations and they would still be their first choice. While $29 \%$ said they would change gas stations within the next 6 months. It shows that there are possibility consumers to change gas stations in the future, depends on their needs and satisfaction.

TABLE 4. PossibILITY FOR SWITCHING Gas STATION

\begin{tabular}{|l|c|c|}
\hline \multicolumn{1}{|c|}{ Frequency } & Number of consumers & Percentage (\%) \\
\hline Yes & 37 & 29 \\
\hline No & 92 & 71 \\
\hline Total & $\mathbf{1 2 9}$ & $\mathbf{1 0 0}$ \\
\hline
\end{tabular}

The higher the level of competition provides many choices for consumers; companies must compete to meet the additional needs of consumers at gas stations in the future. Table 5 shows future consumers needs at gas stations are Food \& Beverages Vending Machine with $30 \%$, Quick Cleaning with $23 \%$, and fuels delivery service with $13 \%$. 
TABLE 5. Future CONSUmers NeEds At Gas Station

\begin{tabular}{|l|c|}
\hline \multicolumn{1}{|c|}{ Future Consumers Needs } & $\begin{array}{c}\text { Percentage } \\
\text { (\%) }\end{array}$ \\
\hline Self service & 10 \\
\hline Fuels delivery service & 13 \\
\hline Vehicle parking care & 8 \\
\hline Quick cleaning & 23 \\
\hline Electric vehicle fast charging & 11 \\
\hline Co-working space & 3 \\
\hline Food \& beverages vending machine & 30 \\
\hline Free nitrogen & 2 \\
\hline Total & $\mathbf{1 0 0}$ \\
\hline
\end{tabular}

Future consumers need at gas stations as shown in Table 5 will certainly be an opportunity for the oil gas company who operate gas stations in DKI Jakarta \& Banten to add new services and income opportunities. In addition, this can be a differentiator with other gas stations.

\section{CONCLUSIONS}

Based on descriptive analysis, it is found that access and location that is easy and affordable are the main reasons consumers choose gas stations with $24 \%$, followed by the accuracy of the fuel dose with $22 \%$ and the good quality of services with $17 \%$. Whereas for future consumers needs at gas stations are Food \& Beverages Vending Machine with 30\%, Quick Cleaning with $23 \%$, and fuels delivery service with $13 \%$.

\section{REFERENCES}

[1] [BPH Migas] Badan Pengatur Hilir Minyak dan Gas,. Komoditas Bahan Bakar Minyak (BBM). Jakarta: Penerbit BPH Migas RI, 2005.

[2] Badan Pusat Statistik Provinsi DKI Jakarta. 2020. Provinsi DKI Jakarta Dalam Angka 2020 [internet]. Doi: https://jakarta.bps.go.id/publication/2020/04/27/20f5a58abcb80 a0ad2a88725/provinsi-dki-jakarta-dalam-angka-2020.html

[3] Dillon HS, Laan T, Dillon HS. Biofuels: At What Cost? Government Support for Ethanol and Biodiesel in Indonesia, Global Subsidies Initiative of the International Institute for Sustainable Development, Geneva, 2008.

[4] Sihombing BF, Lisdiyono E, Governance and the role of legal aspects in the fuel pricing in indonesia. International Journal of Energy Economics and Policy, 8(3), 2018, 168-176.

[5] Jung H, Kyoung-min Kwon, Gun JY, Fuels sales through retail chains and their store traffics and revenue. Asia Pacific Journal of Marketing and Logistics, 32(1), 2019, 2-13.
[6] Sugiyono, Metode Penelitian Kuantitatif Kualitatif dan R\&D, Bandung (ID): Alfabeta, 2008.

[7] Fraenkel, J. \& Wallen, N, How to Design and evaluate research in education. (2nd ed), New York: McGraw-Hill Inc, 1993. 